\title{
American security strategy towards terrorism after September 11 attacks
}

\author{
Wael Zakaria Farag \\ Daleel Company, Giza, Egypt
}

\begin{abstract}
Purpose - The purpose of this paper is to examine evolution of the American strategy toward terrorism in the aftermath of the events of September 11, 2001. In other words, this study revolves around a key question: How and why the American security strategy toward terrorism evolved in the aftermath of the September 11 attacks in 2001? Based on the neorealist approach in international relations, this paper attempted to answer that question: first, through defining the concept of terrorism and how the Americans perceive it; second, via pinpointing the characteristic of the American counter-terrorism strategy before September 11 attacks; and third, through examining the effects of those terrorist attacks on that strategy.

Design/methodology/approach - The nature of the subject of this study calls for reliance on the analytical descriptive approach to highlight the role and strategy of the USA in the fight against terrorism following the events of September 11, in addition to the use of the system analysis methodology, which can identify the inputs and outputs of the system that had an impact in formulating the US counter-terrorism strategy.

Findings - This study has come up with seven findings. The first finding was that the $9 / 11$ attacks served as a turning point of the US counter-terrorism strategy and restructured its agenda. Confronting the communist threat had been its primary objective, until terrorism came to the fore and became its first and foremost priority. The USA vowed that terrorism is its enemy and waged the war on terror to thwart its risk as a global threat. The second finding revolves around the idea of double standards in the American foreign policy. True to its long-standing tradition of favoring its own interests, in complete disregard of the interests of any other party, the USA continued to uphold the double-standards policy.

Originality/value - This study adds a new study to the Arab Library in the field of counter-terrorism studies, national security strategies and American foreign policy. In addition, the researcher seeks to complete the scientific effort to study the US strategy against terrorism, with a clear impact on the development of the situation in the region. This study contributes to the study of how one of the great powers in the international system, the USA, deals with the terrorist organizations that have become widespread in the Arab region.
\end{abstract}

Keywords September, 11th, Anti-terrorism

Paper type Research paper

\section{Introduction}

It has been argued that September 11 attacks in 2001 represented a historical watershed in the American security strategy regarding terrorism. While confronting the communist influence has been the crux of the American security strategy during the Cold War and even

(C) Wael Zakaria Farag. Published in Review of Economics and Political Science. Published by Emerald Publishing Limited. This article is published under the Creative Commons Attribution (CC BY 4.0) licence. Anyone may reproduce, distribute, translate and create derivative works of this article (for both commercial and non-commercial purposes), subject to full attribution to the original publication and authors. The full terms of this licence may be seen at http://creativecommons.org/licences/by/4.0/ legalcode

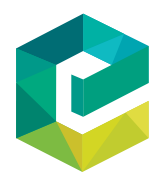

$$
\begin{array}{r}
\text { Review of Economics and Political } \\
\text { Science } \\
\text { Vol. } 5 \text { No. } 4,2020 \\
\text { pp. } 323-333 \\
\text { Emerald Publishing Limited } \\
\text { e-ISSN: } 2631-3561 \\
\text { p-ISSN: } 2356-9980 \\
\text { DOI } 10.1108 / \text { REPS-10-2018-0010 }
\end{array}
$$


REPS

5,4

324

after, the sudden destruction of the two main tours in the heart of the USA shifted that crux into combating terrorism worldwide. In addition, it has been contended that such events had changed the American perception of security threats, especially those coming from the Middle East and the Arab countries; the USA realized the vulnerability of its security and that they are no longer far from being attacked or targeted from within. This new perception has resulted in a strategic shift in the American visions and even priorities of its domestic and foreign policy.

This paper argues that the new US counter-terrorism strategy, in the aftermath of attacks, has been anchored in two main pillars: the first is the use of hard power, which stems mainly from its military capabilities and its economic power, and the second is the use of soft power, which relies on its persuasive capabilities that emancipate from its attractive political culture and values. Against that backdrop, this paper seeks to examine evolution of the American strategy toward terrorism in the aftermath of the events of September 11, 2001. In other words, this study revolves around a key question: How and why the American security strategy toward terrorism evolved in the aftermath of the September 11 attacks in 2001? Based on the neorealist approach in international relations, this paper attempted to answer that question: first, through defining the concept of terrorism and how the Americans perceive it; second, via pinpointing the characteristic of the American counterterrorism strategy before September 11 attacks; and third, through examining the effects of those terrorist attacks on that strategy.

\section{Pillars of the American strategy toward terrorism}

Terrorism has become a weapon used by states, groups and individuals in the developments of weapons technology and the possession of quite a few countries of weapons of mass destruction. It represents the most dangerous challenge facing the world community in the 21st century (Metwally, 2006; Saul, 2008). The idea of terrorism has been confined to the states, as actors, until the end of the Second World War. However, such view of terrorism has been evolved to include organized crime, terrorist organizations and individuals (Mahmoud, 2004). In this section, this paper addresses the foundations of the American strategy toward terrorism through defining the American concept of terrorism and the pillars of the US strategy against terrorism.

There have been numerous and even contested definitions of terrorism. Some people define terrorism as "a violent conflict approach aimed at giving preference to the views of a political minority that seeks to impose its view over society and to tighten its control over the states capabilities and even to obtain political power by using violence through a psychological effect that changes in the direction of the political states" (Abdel Hadi, 1986). Lexical "Aloisi" defines terrorism as each act that aims at overthrowing the legal and economic conditions that the state is anchored in (Dabara, 1990). While Lexical "lesker" define terrorism as a criminal activity characterized by violence and aimed at intimidation to achieve political objectives (Abdel Fathah, 2008).The Encyclopedia of politics defines terrorism as "the use of illegal violence and threats in its various forms, such as assassination, mutilation, torture, vandalism and destruction, in order to achieve a specific political goal, such as breaking the spirit of resistance and commitment to individuals, of the means of obtaining information or money, and in general the use of coercion to subject a party to the will of terrorist" (Massoud, 2013).

Against this background, there is no agreement among the political and legal scholars of a specific definition of terrorism, which makes such term a subject of much controversy. Therefore, countries adopt the definition of the terrorist phenomena according to their political interests, and that is why each country defines terrorism, resistance and self- 
defense differently. The international community and regional organizations have exerted a great effort to reach a comprehensive and united definition of all types of terrorism; however, it failed because of the differences of international views and political trends and interests throughout the international community. Anchored in the absence of a unified definition of terrorism, the USA adopted its unique definition of terrorism. It not a surprise that the USA has always sought to achieve its interests without taking into consideration the interests of the other countries. That is why the Arab pundits have always depicted the American foreign policy of being based on double standards, as evidenced by its policy on the Palestinian issue, when the action taken by the Palestinian movements and faction against the colonist Zionist entity is considered an act of terrorism, and accordingly, they call these movements and factions terrorist organizations, while the action carried out by the Zionist entity against the unarmed Palestinian people is considered a self-defense.

It is worth mentioning that there have been numerous American definitions of terrorism based on the departments at the each American administration at office (US Department of Justice, 1984). Here is some examples of terrorism definition in the USA: while FBI defines terrorism as " [... . a violent action or work that poses a threat to human life and violates the inviolably of criminal laws in any country" (Headquarters, Department of the Army, 1983) (8), the US department of defense, defines terrorism as follows: "to use or threaten the unlawful use of force or violence by a revolutionary organization" (Army, 1986). The Ministry of Justice defines it as a "Violent criminal behavior clearly intended to influence the conduct of government by assassination or abduction." And finally, the Ministry of foreign Affairs, defines terrorism as follows:

Politically motivated violence committed by the former against the conception and design against non-military targets by national sub-groups or agents of secret country and usually meant to influence an audience (Calinickus, 2020).

This is what can be said about the presence in dealing with these terrorist phenomena by not looking at their causes and motives and then the possibility of dealing with these issues to eliminate these terrorist phenomena in addition to exploiting them to influence the international system and pass policies and strategies that serve the interests of major powers in the international system.

Anchored in the American definition of terrorism, the US counter-terrorism strategy is based on two pillars: the use of hard power which derives primarily from military capabilities and economic power, and the use of soft power which relies on the idea of persuasive ability and cultural attractiveness. As for the first pillar, hard power, there are two forms of the American repeated use of hard power: the first is the threat of use force in the mode of deterrence or coercion, which is a threatening practice aimed at influencing the management of the adversary in a manner that prevent him from carrying out a certain behavior that wishes to "deterrence" or push toward certain behavior that he does not wish to do "coercion." The second is the actual use of military force of which is related to the use of combat in the framework of the pattern of defense or pattern of attack against the forces or capabilities of the opponent with the purpose of causing destructive effect associated with the purpose of military operations (A1-Kaoud, 2016).

The mainstay at the use of hard power in the war on terrorism is the use of military face to eliminate terrorist groups. The American army, along with the Allied forces in the war, plays a key role in the implementation of this objective, which is based on pre-emptive strikes and simple military positioning within the countries that are witnessing the growth of terrorist groups. This is the practice of the American military troops deployed in the world and the reliance on the partners in the fight against terrorism, which is considered a 
REPS

5,4

part of the regions that have been identified as a field for this war. The war against al-Qaeda in Afghanistan and Iraq fought by the USA for the purpose of eliminating terrorism is one of the most important uses of hard power against terrorism (Khashana, 2017).

As for the second pillar, soft power, it can be defined as "the ability to get what you want through persuasion and not coercion (Weinbrenner, 2007). Its tools are political and cultural values, global capabilities, scientific and intellectual exchange, the ability to build bridges, establish alliances(21). In other words, the concept of soft power in American foreign policy has been marked by goals related to changing the tool of war from military power to soft power, manifested in their cultural, economic and media tools. The US policy-makers have come to realize that the war on terror, especially in countries where the threat of terrorism is endemic, is a war of peculiar nature, such that renders robust military intervention (i.e. hard power) either irrelevant or inadequate. To combat terrorism, they opine, the military approach should be complemented by (and interwoven with) non-military approaches (Bin Al-Sheikh, 2014/2015).

Coinciding with the surge in studies pushing for a more diplomacy-based counterterrorism strategy to gain international support, the USA has opted to place more weight on soft power in its fight against terrorism. The US's soft power has taken the form of economic aids, development incentives and, in cases where the government was too weak to maintain security, training of security personnel. In a leaked memorandum, dating back to 2003, Donald Rumsfeld, then US Secretary of Defense, urged his top subordinates to think of new techniques to wage a "war of ideas against terrorism." "To win the war on terror," said Rumsfeld, "military victories are no more adequate; it's important to win the battle of minds too" (Bin Al-Sheikh, 2014/2015, p. 35).

In what amounts to a shift in the US political discourse, closer attention was paid to the terrorists' ideological power, and hence, the colossal influence of their thoughts and beliefs was acknowledged by the American politicians. As reported in the Washington Bulletin, on August 20, 2004, Condoleezza Rice, then US National Security Adviser, gave a speech, on August 19, centered on the efforts made by the US Government to conquer terrorism in the Middle East. She made clear that to secure a victory in the counter-terrorism war, winning the ideological war was deemed indispensable. Addressing the US Institute of Peace, WA, Rice stressed that the fight against terrorists would be a long one. She underscored the 9/11.

Commission calls for developing a political strategy, to work side by side with the military one and to wage a "war of ideas" on terrorism. In 2014, the former US President, Barrack Obama, sought the Congress approval of allocating $\$ 5 \mathrm{bn}$ for training non-US security forces and providing the necessary assistance in their fight with terrorists (Bin AlSheikh, 2014/2015, pp. 35-37).

\section{9/11 attacks' core features}

It was such a tragic start into the 21st century, when the series of coordinated terrorist attacks hit the USA on the morning of Tuesday, September 11, 2001, leaving behind a staggering death toll, let alone thousands of injuries. The world's hegemon that had long boasted its immunity against terrorism was stricken by the deadliest terrorist attacks that ever happened. It was not long before the Bush administration pointed to al-Qaeda and its leader, Osama bin Laden (who had been sent to exile by the Saudi authorities), as being behind the attacks. Al- Qaeda stronghold had been embraced by the Taliban in the areas under their control in Afghanistan. Therefore, assisted by the UK, the USA led an international coalition to launch a robust military operation intended to eliminate al-Qaeda and depose the Taliban regime (Al Nunwa, 2003). 
In many respects, the world after the $9 / 11$ disaster is not like the world before it. It brought the Western powers face-to-face with their limitations, at least so far as the material power is concerned. Ever since, international security has been attached greater importance and put on top of the international agenda. While it is true that the definitions of security vary greatly, according to the level and scope of analysis, as well as the adopted theoretical and methodological framework, we can hardly find a definition that does not recognize terrorism as arguably the most serious of all dangers, facing the developed and developing countries alike. For some, the gravest of these dangers comes from domestic terrorist groups, which, with their abundant supplies and coherent organizational architecture, may take their respective countries hostage. As they work in a stealthy, insidious way, taking advantage of their liquid (but cohesive) setup, they become extremely hard to detect. In the face of such an untraditional threat, it was imperative to come up with no less untraditional strategies to combat it; strategies that go beyond the conventional security paradigms and place more emphasis on the economic and governance-related aspects, with a view to prompting or fueling socio-political developments in South Asia (Al Nunwa, 2003, pp. 3-4).

Granted, the 9/11 terrorist attacks were not the first to afflict the world in general. Nor were they the first to befall the USA in particular. Nevertheless, six core features could be discerned as setting the 9/11 attacks apart from any other terrorist attack in today's world. The first feature revolves around the fact that the attacks targeted strategic objects of paramount magnitude, such that undermined the US status as a leader of the international system and gravely hurt the American pride. As a result, the Bush administration conducted a comprehensive and thorough review of the concept of national security, along with its institutions, programs and strategies. The second feature of the attacks was that it was not a war waged by a certain foreign country. Nor was it an act of terror conducted by a definite number of terrorists from whom the USA could have taken vengeance to restore its status and national dignity. As such, the USA found it indispensable to declare war against all the terrorist groups possibly standing behind the attacks. This implicated that the US response would not be limited to a certain military object that, once destroyed, the targeted terrorist groups would be eliminated, or the danger of terrorism would be dismantled. Rather, such a war would take the form of pursuing terrorist groups and targeting their strongholds inside certain countries.

The third feature of the attacks materialized in the fact that none of the nation-states were involved in the attacks, neither directly or indirectly. A country's calculations are different from those of the individuals. And no country in today's world, no matter how hostile to the USA, would take such a risk as to partake in a deadly terrorist attack against it. From this, it could be inferred that the attackers were most likely religious hardliners who took an extremist stance toward the US political and military policies. The fourth feature revolved around the idea of proportional response; in order for the US response to be proportionate with the magnitude of casualties and to achieve deterrence, the losses to be incurred by the attackers were supposed greater and more painful than those incurred by the USA - which was not the case.

The fifth feature was the fact that the attacks were not initiated from outside the USA, but from within, through its airports and other government organs. Not only did this bring into question the American immunity claims but was also devastating of the reputation of the US security authorities, in light of how the attacks were carried out. Besides, the USA was the sole target of those attacks - which implies that they were a reaction to the US policies and stances. The final feature manifested in the fact that the attacked country, i.e. the US, had not acted alone on certain international issues that might have triggered the attacks (such as globalization, domination over the World Bank and International Monetary
American security strategy towards terrorism 
REPS

5,4

Fund) As a matter of fact, the USA had been accompanied, joined or followed, by several international powers (most notably the NATO member states) in espousing the same policies. Therefore, acting out of vulnerability and shared threat perception, those powers joined the USA in its fight against terrorism (Encyclopedia of the Desert Fighterm, 2017).

\section{Post-9/11 US counter-terrorism strategy}

In the wake of the 9/11 attacks, the US Congress established, toward the end of 2002, the National Commission on Terrorist Attacks Upon the United States, also known as the 9/11 Commission, with the aim of explaining the attacks and putting forth recommendations to avoid their recurrence in the future. In its final report, the Commission came up with a host of recommendations that could be summed up as follows:

Regarding the counter-terrorism approach, the report recommended that it be a balanced and comprehensive approach - such that targets all terrorist organizations and harnesses all the US potentials to seize terrorists, destroy their strongholds, thwart their schemes, defuse their dangers and deprive them of safe shelters - and in the meantime maintain stability of the host countries. In addition, the report recommended forming a coalition of the countries willing to carry out this mission and encouraging an East-West dialogue, placing a particular emphasis on the nonproliferation of weapons of mass destruction. Moreover, the report assured the significance of maintaining a higher level of security for the means of transport in the USA and ensuring stricter border control, as well as putting into force an immigration control system that enables identifying terrorists to prevent them from entering into the USA. Furthermore, the report referred to the necessity of staying on standby for any potential attacks and educating the American people and training competent staffers on anticipating the potential scenarios. It also recommended establishing the US counter-terrorism center to coordinate and orchestrate the efforts of the various US intelligence and security agencies, including the FBI and introducing amendments to the Congress intended for consolidating efforts and granting the intelligence agencies sufficient powers to do their job, by maintaining security US-wide (Encyclopedia of the Desert Fighterm, 2017, pp. 225-226).

Following the attacks of September 11, 2001, the State Department's Bureau of Counterterrorism declared the East Africa and Horn of Africa regions (especially Djibouti, Somalia, Ethiopia, Eretria, Kenya and Tanzania) as dangerous regions. And in 2003, the USA launched the East Africa Counter-Terrorism Initiative (EACTI) and allocated to it $\$ 100 \mathrm{~m}$ to spend on military training on border and coast screening, fund programs for tightening oversight and control over transborder mobility of individuals and goods and launch regional programs aimed at fighting terrorism and depleting its resources, in addition to police training, development of counter-terrorism educational programs and anti-money laundering programs. It is worth noting that Kenya made better use of that initiative than any other East African country did; in close coordination with Washington, Kenyan officials developed a comprehensive system to combat money laundering and terrorism financing (Ahmed, 2010).

Furthermore, the US State Department's Counter-Terrorism Program introduced the PIT System to the airports of Kenya, Tanzania, Ethiopia, Dibouti and Uganda. It is a computerized system designed to help the authorities detect the illicit attempts to get into or out of their respective countries. Not only that, the USA has also funded training programs to qualify and develop the security forces of Tanzania, Uganda, Ethiopia and Kenya. That notwithstanding, in a Congressional hearing held in April 2004, Ed Royce, then Chairman of the House Foreign Affairs Subcommittee on Terrorism, stressed that the USA was still 
required to allocate more resources for counter-terrorism in Africa, as the approved allotments were still insufficient to overcome the threats there (Shinn, 2004).

On the whole, the post-9/11 US counter-terrorism strategy could be approached from two distinct standpoints: the post-9/11 US security measures and the US counter-terrorism legislations and administrative policies.

American security strategy towards terrorism

\section{Post-9/11 US security measures}

Following the tragic attacks of September 11, 2001, the Bush administration adopted a host of security measures, most notably the following:

- September 23: by virtue of the Executive Order no. 13224, all property (or interests in property) of the 27 individuals and entities whose names were designated as committing, supporting or sponsoring terrorism were blocked. And it was decreed that the assets of those who committed (or had the potential to commit) terrorist crimes be blocked.

- September 28: the USA submitted to the United Nations Security Council (UNSC) the resolution no. 1,373, binding all UN member states to criminalize financing of terrorists, with a view to depriving terrorists, wherever they might be, from their incubators.

- October 5: the US Secretary of State, in coordination with the Attorney General and Secretary of the Treasury, added 25 names (including al-Qaeda) to the list of foreign terrorist organizations. Pursuant to the Anti-Terrorism and Effective Death Penalty Act of 1996, it should be noted, providing financial support to any such terrorist organizations shall be criminalized.

- October 12: the US administration added 39 names to the list of the individuals and organizations associated with or involved in committing or financing terrorism, pursuant to the Executive Order no. 13,224.

- October 26: the Patriot Act came to force in the USA, substantially widening the discretion of the security forces on cases having to do with terrorism.

- October 29: the Foreign Terrorism Tracking Task Force was created to deny entry into the USA of aliens associated with, suspected in being engaged in or supporting terrorist activity. It also provided for location, detention, prosecution or deportation of any such aliens already present in the USA.

- The USA signed the UN Terrorist Financing Convention (short for: International Convention for the Suppression of the Financing of Terrorism) and the UN Terrorist Bombing Convention (short for: International Convention for the Suppression of Terrorist Bombings).

- The USA held multilateral meetings with regional organizations with the aim of exchanging the strategic and tactical information stipulated by the UNSC Resolution 1373.

- The Federal Bureau of Investigation (FBI) formed a financial investigation workgroup synthesized of all relevant agencies to explore the financial arrangements adopted to support terrorist attacks. The workgroup included experts and detectives from all FBI agencies and was supported with two FBI agents with extensive expertise in investigating financial crimes and suing those involved.

- The US entry visa was redesigned in such a manner that makes it hard to forge, and improvements were introduced to the passports to prevent replacement of the passport-photo. 
REPS

5,4

- Intense talks were held with Canada and Mexico to tighten security measures along the common borders with the USA (Metwally, 2006).

\section{US counter-terrorism legislations and administrative policies}

The counter-terrorism legislations and administrative policies enforced by the USA post-9/ 11 could be summed up as follows:

\section{Establishing the homeland security office}

On September 20, 2001, President George W. Bush of the USA declared establishment of a new office reporting directly to the White House - that was the Homeland Security Office. Tom Ridge, then governor of Pennsylvania, was named director of that office. Eight months before the first anniversary of the September 11 calamity, the office developed into a fullfledged federal executive department: Department of Homeland Security. And Ridge became the first Secretary of Homeland Security. The Department's first and foremost objective was to address domestic security issues. Besides, the Terrorist Threat Integration Center was set up to orchestrate the efforts of the various US intelligence agencies. Moreover, Bush stressed that his administration took numerous measures to maintain security of the trucks, ships and aircrafts heading to the USA. Added to this, high-tech explosives detectors were deployed in strategic sites across the country to detect explosives and thwart attacks.

\section{Counter-terrorism and aviation security legislations}

Of the post-9/11 legislations, the USA Patriot Act stands out as the most important and most controversial. The Act provided for unprecedentedly wide jurisdictions for the US security agencies in the face of terrorism. For instance, the US Attorney General was authorized, by virtue of that legislation, to keep the foreigners suspected of engagement in terrorist acts under arrest for up to seven days before filing charges against them. He was authorized, also, to tap phone calls and get access to the suspects' email accounts from the internet service providers.

The Congress, for its part, responded to the September 11 attacks by passing the Act with an overwhelming majority. The USA Patriot Act is the short form of "Uniting and Strengthening America by Providing Appropriate Tools Required to Intercept and Obstruct Terrorism Act of 2001." The Act covers a myriad of policy areas (or "titles"), ranging from surveillance and immigration control, to anti-money laundering, through to compensation of victims and their families, among many other policy areas. In other words, the Patriot Act was a synthesis of miscellaneous legislations that amended, enforced or widened the scope of existing federal laws.

In addition, the Congress ratified the Aviation and Transportation Security Act (ATSA) that provided for creating the Transportation Security Administration, for the purpose of maintaining all US air and maritime ports. ATSA made it mandatory that all passengers and baggage be screened by $\mathrm{x}$-ray devices and sniffing dogs. Aside from the those legislations, President Bush issued an executive order providing for forming military courts to try foreign terror suspects, especially al-Qaeda members, or those involved in assisting or protecting them. The rulings of those courts, approved by a two-thirds supermajority, were deemed final and unappealable (Metwally, 2006, pp. 229-235). 
the form of terrorism involving the use, or threatened use, of biological agents against a person, group, or larger population to create fear or illnesses for purposes of intimidation. Bioterrorist acts may be committed by an individual or a group of individuals, usually with an extremist towards background, for gaining an advantage, or imposing certain political or religious thoughts.44

Given how risky this form of terrorism is, the Congress passed the Project Bioshield Act of 2004 (S. 15), in response to the anthrax and ricin attacks against many of the US Government agencies, including the Congress itself. By virtue of that Act, $\$ 5 \mathrm{bn}$ was allotted to spending on a ten-year program to acquire medical countermeasures to attacks of anthrax smallpox and the like bioterrorist attacks.

\section{Blocking terrorist property}

On September 23, 2001, President Bush signed Executive Order 13224 pursuant to the authorities of the International Emergency Economic Powers Act. The Order, that provides for a means by which to disrupt the financial support network for terrorists, stipulated blocking the property or interests in property of all the individuals and entities designated by the President or the Secretary of State as committing, or posing a significant risk of committing, acts of terrorism that threaten the security of US nationals or the national security, foreign policy or economy of the USA.

\section{Restructuring the department of justice}

Led by John Ashcroft, then Attorney General of the USA, the Department of Justice (DOJ) played a paramount role in the war on terror. Aside from its traditional roles (centered on prosecution and investigation), the Department adopted a more proactive approach aimed at preventing terrorist attacks. Also, a DOJ unit was created to pursue foreign terrorists, prevent them from entering the USA and capturing those who have already entered.

\section{Conclusion}

This study has come up with seven findings. The first finding was that the 9/11 attacks served as a turning point of the US counter-terrorism strategy and restructured its agenda. Confronting the communist threat had been its primary objective, until terrorism came to the fore and became its first and foremost priority. The USA vowed that terrorism is its enemy and waged the war on terror to thwart its risk as a global threat. The second finding revolves around the idea of double standards in the American foreign policy. True to its long-standing tradition of favoring its own interests, in complete disregard of the interests of any other party, the USA continued to uphold the double-standards policy. This well manifested by its attitude toward the Palestinian cause. For, while it considers the acts of the Palestinian movements and factions against Israel as terrorist attacks, and hence labels all such movements and factions as terrorist groups, it defends the crimes committed by Israel against a peaceful, unarmed people as being a self-defense. In other words, for the purpose of maintaining the US and Israeli interests, the US administrations are in the habit of conflating terrorism with resistance.

The third finding maintain that the US counter-terrorism strategy is based on two pillars: the use of hard power (drawing mainly on military capabilities), and the use of soft power (having to do with the economic power, normative power and cultural attraction). Whereas the fourth finding revolves around the idea of how to counter terrorism, where US policymakers have come to realize that the war on terror, especially in countries where the threat 
REPS

5,4

of terrorism is endemic, is a war of peculiar nature, such that renders robust military intervention (i.e. hard power) either irrelevant or inadequate. To combat terrorism, they opine, the military approach should be complemented by (and interwoven with) non-military approaches. The fifth finding is the fact that the post-9/11 US counter-terrorism strategy could be approached from two distinct standpoints: the post-9/11 US security measures, and the US counter-terrorism legislations and administrative policies.

The sixth finding is the fact that the USA took advantage of the 9/11 attacks and the subsequent war on terror to attain a manifold goal. On the one hand, it sought to dominate Afghanistan and thereby wield its influence over Central Asia. On the other hand, it aimed to undermine the Iranian expansion in the region. Besides, it planned to stay at a stone's throw away from the two hostile nuclear powers (India and Pakistan) to thwart any potential war that could alter the balance of power throughout the region. The seventh and in the final analysis, the US counter-terrorism strategy brought together two elements: the strategic, proactive element that took to form of a package of actions and precautions applied domestically to defuse the terrorist danger, in addition to developing a different political discourse in the face of the countries embracing terrorist strongholds, and the deterrence element, through its war on terror, with al-Qaeda being its first target.

\section{References}

Abdel Fathah, E. (2008), Terrorist Crime, New University House, Egypt, p. 74.

Abdel Hadi, A.A.M. (1986), International Terrorism - The Study of International Conventions and Resolutions Issues by International Organizations, Dar al-Nahda al-Arabiay, Cairo, p. 43.

Ahmed, S.E. (2010), US Policy toward the Horn of Africa Conflict, Role and Response, Emirates Center for Strategic Studies and Research, Abu Dubai, pp. 198-199.

Al Nunwa, M.A.H. (2003), The Future of Pakistan after the Sep, 11, 2001 and the United States of America in Afghanistan, UAE Lecture series (68), Emirates Center for Strategic Studies and Research, Abu Dubai, P. 3.

Al-Kaoud, I.K.O. (2016), "The strategy of soft power and its role in implementing the ambiguity of US foreign policy in the Arab region", Master Thesis, Faculty of Arts and Sciences, Middle East University, p. 32.

Army, U.S. (1986), Definition, Army Regulation 190 - 52 as Quoted, D.B. Vought and J.H. Fraser, p. 62.

Bin Al-Sheikh, F. (2014/2015), "The role of the United States in combating terrorism in the African Sahel", Master Thesis, University of Qusada Marbah, Douala, Algeria, p. 34.

Calinickus, A. (2020), The Great Strategy of the American Empire, Center for Strategic Studies, No Publication Year, p. 102.

Dabara, M.M. (1990), Terrorism Concept in International Criminal Law", Publications University and Qaryounis, Benghazi, Libya, P. 128.

Encyclopedia of the Desert Fighterm (2017), "Terrorism and first wars of the century", available at: www.moqatel.com/openshare/Behoth/Siasia2/Erhab/sec03.doc_cvt.htm. (accessed 12 September 2018).

Headquarters, Department of the Army (1983), Dictionary of US Army Terms (Army Regulations 310 25), Military Publications, Washington, DC, p. 71.

Khashana, R. (2017), "From Afghanistan to Africa: Has the focus of Washington's war on terrorism shifted to the Sahel?", available at: http://studies.ajazeera.net/files/isil/2014/11/2014112392645853193.html. (accessed 12 September 2018).

Mahmoud, A.I. (2004), “The new terrorism, journal of international politics", Cairo, Al-Ahram Center for Political and Strategic Studies, No. 147, pp. 44. 
Massoud, A.A. (2013), "The distinction between terrorism and resistance to occupation in light of the principle of the right to self-determination "legal study within the framework of the rules of international law", Master's Theses, Institute of Arab Studies and Research, Department of Legal Studies, League of the Arab Nations, pp. 83-85.

Metwally, M. (2006), Strategic Planning in Combating International Terrorism Crimes, "Comparative Study", Scientific Publishing Council. Kuwait University, State of Kuwait, p. 5.

Metwally, M. (2006), "Strategic planning in combating international terrorism crimes", Comparative

Study, Op.Cit, pp. 247-248.

American

security strategy

towards

terrorism

Saul, R. (2008), Defining Terrorism in International Law, Oxford University Press, Oxford, p. 3.

Shinn, D.H. (2004), Fighting Terrorism in East Africa and the Horn, Foreign Service Journal, American Foreign Services Association, Washington, DC, pp. 41-42.

US Department of Justice (1984), "Testimony by Victoria tensing, deputy assistant attorney general", Criminal Division, p. 110.

Weinbrenner, J. (2007), "Soft power and hard power approaches in United States foreign policy: a case study in Latin America", Master Thesis, University of Florida, pp. 40-43.

\section{Corresponding author}

Wael Zakaria Farag can be contacted at: Kandel.wela@yahoo.com

For instructions on how to order reprints of this article, please visit our website: 